\title{
Some Key Factors Influencing Attitudes to Patronage of GSM Services: The Nigerian Experience
}

\author{
Ogwo E. Ogwo ${ }^{1} \&$ Sunny R. Igwe ${ }^{2}$ \\ ${ }^{1}$ Department of Marketing, Abia State University, Uturu, Nigeria \\ ${ }^{2}$ Department of Marketing, University of Port Harcourt, Choba, Nigeria \\ Correspondence: Sunny R. Igwe, Department of Marketing, University of Port Harcourt, P.M.B 5323, University \\ of Port Harcourt, Choba, River State, Nigeria. Tel: 234-803-318-2496. E-mail: Chikordi@yahoo.com
}

\author{
Received: May 16, 2012 Accepted: July 16, 2012 Online Published: September 16, 2012 \\ doi:10.5539/ijbm.v7n18p82 URL: http://dx.doi.org/10.5539/ijbm.v7n18p82
}

\begin{abstract}
The increasing pattern of customer switch, competition and the quest for customer loyalty in Global System for Mobile communication (GSM) industry informed the study of some key factors influencing attitudes of customer towards of mobile phone services. A cluster and simple random survey were employed on 308 university lecturers in the South-South region of Nigeria. Spearman rank correlation and multiple regressions were used to test the hypotheses. The 'model' based on empirical findings revealed that service quality, customer value, brand image/reputation each positively and significantly influences intention to use. The moderating effect of satisfaction is contingent, necessary and sufficient upon the level of these antecedent constructs' influence on intention to use. The implication of this work to both researchers and practitioners is discussed.
\end{abstract}

Keywords: intention to use, service quality, brand image, customer value, satisfaction, GSM

\section{Introduction}

The world is fast becoming a global village. Information, communication and mobile telephony will certainly make it practicable. Using mobile phones has become indispensable. Mobile phones are fast dramatically spreading to the remotest parts of the world (Friedrich et al., 2009). Reportedly, by 2015, more than half of the world inhabitants are expected to be using mobile phones (World Telecommunication /ICT Development Report, 2010). What is evident is that Global System for Mobile communication (GSM) has been playing a significant and stimulating role to most nations' economic development in the last few decades (Paul et al, 2010). In Nigeria, with democratization and the inception of GSM in 2001, and with a growing population of about 160 million people and 78\% subscribers Tele -density, the industry has increased from NITEL (or government monopoly) to a highly competitive market with market share spread of 46.19\%, MTN; $26.87 \%$, Glabacom; 24.74\%, Zain (Celtel, now Airtel); 1.76\%, Etisalat; and 0.44\%, Mtel (NCC Report, 2009). More operators are expected to be licensed in the near future. GSM has contributed significant increase of 3\% - 4\% in 2009 to the Gross Domestic Product (GDP), to technology transfer, and employment in Nigeria (Gabriela and Badii, 2010), It has also contributed indirectly to the correction of market inefficiency, transport substitution, risk aversion and social cohesion (Asheeta, Rowena, Subramanian \& peter, 2008). But with a critical look, however, it does not appear that the full potential of GSM is being exploited in the world. Scholars, professionals and policy makers who show keen interest to the industry are worried on how to sustain this growing and influential role of telecommunication, as many research questions about how to sustain customer patronage remain unanswered.

Currently, GSM operators have realized that retaining existing customers is as important as acquiring new ones (Coyles and Gokey, 2005). In view of this, operators now strive to determine what factors influence customer patronage. Though, the complicated interrelationship among key constructs; service quality, brand image, customer value, customer patronage, and satisfaction have not been fully uncovered and understood (Jones and Sasser, 1995), yet it has been found that in different countries unique factors play active role in influencing customer patronage and loyalty in mobile telecom markets (Gerpott, Rams \& Schindler, 2001; Ahn, Hun \& Lee, 2006; Ranaweera and Neely, 2003; Lee and Feick, 2001). Aside these key factors -service quality (Wan-Jin, 2009); brand image (Boohene and Agyapong, 2011) and customer value (Varki and Colgate, 2001), other studies (see; sociodemographic (Bigne Ruiz \& Sanz, 2007); inertia, indifference (Ranaweera and Neely, 2003); switching cost ( Keaveney, 2003) customer service and price (Gerpott et al., 2001); trust and self-efficacy (Quan, 
Hao \& Jianxin 2010); satisfaction (Martin-Consuegra, Molina \& Esteban, 2007) on significant factors influencing attitudes have been done but we cross-validate these three key significant constructs in an emerging viable market segment in Nigerian growth stage of GSM industry. Similarly few studies have been done in Nigeria- Muminu, Anuluwapo and Aderemi (2002) only considered networks attributes, Aminu and Hartini (2008) considered marketing mix value added service, price and promotion while Oyeniyi and Abiodun (2009) looked at only customer service and switching cost.

None of these studies (e.g Gerpott et al., 2001; Muminu et al., 2002; Bolton and Drew, 1992; Cronin, and Taylor, 1992) measured and focused on service quality as (no network service during extreme weather and during heavily celebrated festive period (e.g Christmas and muslim sala seasons) and wider service coverage reaching all rural and urban cities in Nigeria) as commonly experienced in Nigeria nor did any study (e.g Blumetha and Berystrom, 2003; Nguyen and Leblanc, 2001; Yi, Xiaoqin \& Weiqing, 2008; Keller, 2001) on brand image measure it as amount of free tariff bonuses and level of partnering and Corporate Social Responsibility (CSR) investments to both urban and rural villages. Comparing Zeithaml (1988); Woodall (2003) ;Woodruff (1997) and Kollman (2000) studies on customer value, additionally our study focused and measured value as price "high" comparison (both global and local competitors) and personal usefulness of GSM before and after GSM introduction, since GSM was lately adopted in Nigeria compared to neighboring nations. These studies (Gerpott et al., 2001; Ahn et al., 2006; Ranaweera and Neely, 2003; Lee and Feick, 2001; Aminu and Hartini (2008) on attitude, loyalty and retention have generally measured intention to use as a mere weaker customer volition: want, expectation and plan; and neglecting a stronger passion as "emotionally attachment/commitment" to use GSM as this study measures. Since GSM is seen more now as both ones' indispensable social way of life tool and communication tool in Nigeria.

These researches above proved insufficient to gain a comprehensive explanation and robust measures of the factors that affect customers' intentions to adopt or reject the use of mobile services, nor did any of them incorporate key constructs in explaining customer patronage of GSM. None of the studies considered consumers in the oil rich area of South- South region of Nigeria of intense socio-economic activity. The goal of the research presented is the explanation of how these three constructs service quality, brand image/reputation and customer value influence the use of future mobile services.

\section{Theoretical Background}

\subsection{Service Quality}

In every service industry, the level of service quality is a significant differentiator and a great competitive weapon which all firms strive to achieve. Service quality and customer service have become marketing priority (Zeithaml, Parasuraman \& Barry, 1996) and are the core basis for consumer behavior and satisfaction. Service quality is a critical component of customer perception - as it is a dominant element in customers' evaluation of a product (Zeithaml and Bitner, 2000). Cronin and Taylor (1994) viewed service quality as a form of attitude representing a long-run real evaluation. Churchill and Surprenant (1982) defined and measured service quality as a belief statement or attribute of performance. Zeithaml (1988) defined service quality as 'the customer's assessment of the overall service excellence'. All these definitions show that service quality is dependent a consumer's attitude, subjective and affective customer's perception on the service provider. This brings us to the concept (model) of four service quality gaps (Zeithaml, Parasuraman \& Barry, 1994). These gaps show which/whose subjective view best describes the concept of service quality. But many have argued that service quality is better defined by the consumer. The model also indicates that the customers' quality perceptions are influenced by a series of four distinct gaps occurring in organizations. Similarly, many scholars agree with the summarized five dimensions of service quality; reliability, responsiveness, tangibles, empathy, assurance of (Zeithaml and Bitner, 2000) and more recently the additional two interactive qualities- Recognition and flexibility. (Gil-lafuente and Luis-Bassa, 2011) and these service dimensions are appreciated more depending on the individual characteristics, level of industry development and extent of competition. Specifically with respect to GSM, it involves accuracy in billing, location of network, keeping records correctly, call time, call drop, voice clarity, interconnectivity, performing the service at the time designated, and wider coverage.

\subsection{Customer Value}

The concept of price or customer value has its origin in equity theory, which consists of the ratio of the consumers' outcome/input to that of the service provider outcome/input (Oliver and Desarbo, 1988). Equity concept refers to customer evaluation of what is fair, right or deserved for the perceived cost of offering (Bolton and Lemon, 1999), and a trade-off between the quality and benefits they perceive in the product relative to the sacrifice they pay (Monroe, 1990). Price is often used by consumers as an extrinsic product-quality cue (Teas 
and Agarwal, 2000). We can deduce that price or customer value is a subjective perception of trade-off between what a customer gives up (price, sacrifice) and what the consumer received (utility, quality, benefits). In the telecom Service industry, there are two price factors users consider before deciding to purchase a GSM product the initial purchase price and usage or retaining charges (tariff). Many have used price as a measure of wealth, value and quality. Because of the nature of the contractual agreement to use a product in the future in the telecommunication service, consumers are more conscious of cost of keeping or using the network and not price of initial buying. Perceived cost includes monetary payments and non monetary payment sacrifices such as time, consumption, energy, stress and risk experienced by a consumer. Apart from the consumers' direct evaluation of product attributes as suggested in Teas and Agarwal (2000) product in-use value and redemption value, the consumer often measures a company's ratio of outcome to inputs by making comparisons with its competitor's offerings.

\subsection{Brand Image/Reputation}

The American marketing association defined brand as any name, term, sign, symbol, or design, or combination of these that identifies the maker/seller of the product or service and differentiates it from competitors. The level of brand awareness, image, identity, association, and reputation are very important in customer choice/patronage. Brand image is the perception about a brand as reflected by the brand as held in a consumer's memory (Kotler, Bouden \& Jane, 2006). Brand awareness is the ability to identify the brand under different conditions, as reflected by their brand recognition or recall performance (Kotler and Keller, 2006), consumer's brand recognition and ability to confirm prior exposure to the brand when given a brand as a cue (Keller, 2003). Brand awareness and image are mostly achieved through marketing communication and promotion. Corporate brand image is a brand that an organization acquires and reflects its heritage, value, culture, people and strategy (Aaker, 2004). Brand's reputation is a perceptual asset in the minds of stakeholders about a performance. Brand reputation is built on by the brand association with other brand identities. In Nigeria, MTN Foundation and Glo sponsorship of football premier league are laudable examples. Marketing program/communication creates brand awareness or image that is used to influence consumer behavior or patronage. Brand cues are not only created by marketing program or communication but through direct experience, brand information, word of mouth, channel members, country of origin and place, In short, everything that has to do with the touch point between the brand and the customers. Ideally, for an organization to achieve brand reputation it must have huge brand equity. Brand equity is the added value endowed to product and service which is reflected in how a consumer feels, thinks, and acts with respect to the brand. Brand image relates or represents most recent perception and fluctuates overtime; by contrast brand reputation is about perception of the brand over time and is more stable.

\subsection{Customer Patronage}

The customer is as old as business. The sole purpose of every business is to "Create Customer" (Drucker, 1973), adding more Drucker (1973) opined that the only economic and social justification existence of any business existence is to create customer satisfaction. The importance of the customer and customer patronage per se is so profound. It includes financial and non financial dimensions. Many studies have been done on what influences or impacts on level of customer patronage. They include- firm's capability, product or services attributes, economic situation, political forces, social and psychological factors, situational, competition, marketing mix programs (Schiffman and Kanuk 2009; Kotler and Keller 2006). Experience indicates that defining and measuring patronage is extremely difficult. Attitude and actual usage patronages have been used as measures of customer patronages. Dick and Basu (1994) precisely suggested that favorable attitude and repeat purchase were required to define patronage. Intention to use is defined as a specific desire to continue relationship with a service provider (Czepiel and Culmore, 1987). Attitudinal measures have an advantage over behavioral measures (actual or repeat patronage) in that they can provide greater understanding of the factors associated with the development and modification of patronage (Oliva, Oliver \& MacMilian, 1992). Fishbein and Ajzen (1975) argue that attitudes are functionally related to behavioural intentions, which predict behaviour. A person's intention to behave in a certain way is contingent upon the attitude toward performing the behaviour in question and the social pressure on him/her to behave in that way (subjective norm).This suggests that attitudes and subjective norms differ according to the person involved and behavioural context. Theory of Planned Behaviour (TPB), which is an extension of Theory of Reasoned Action (TRA), has introduced another factor that affects behavioural intention, which is the perceived behavioural control. Control beliefs and perceived power are the main construct of perceived behavioural control (Mackenzie \& Jurs, 1993). Consumers vary in their commitment to attitude; the degree of commitment relates to their level of involvement with the attitude object. This commitment ranges from inertia to a strong emotional passion. Commitment might be based on customers' intentions as want, expectation, plans for the future (Sunderland, 2002 and 2010) and even emotional attachment 
to a product. We concentrated more in this study on customer's intention to use a product in the future and recommend such to friends.

In the behavioral attitude, behavioral patronage or usage measures are based on observable responses to, object, promotional stimuli-repeat purchases, and number of purchase, usage, behavior, than attitude rather towards the product or brand (Schiffman and Kanuk 2009). Critically, it neglects the psychological aspect of patronage. The theory of reasoned action as expanded from Fishbein's model aims to measure and support behavioral intention, recognizing that certain uncontrollable factors limit our ability to predict the future with 100 percent accuracy.

\subsubsection{Service Quality and Customer Patronage}

In an organization's capabilities and customers' perception and learning, we have seen the role service quality plays in customer patronage and usage of a brand. Several studies established a positive relationship with varying influence levels between transmission/network qualities; network coverage; pricing/billing; data services; and customer service on clients' satisfaction/intention to use, largely in developed nations and/or early market (Bolton and Drew, 1991; Lim et al., 2006; Varki and Colgate, 2001). Similarly, Boulding, Kalra, Staclin \& Zeithaml (1993) found a positive relationship between service qualities and repurchase intention and willingness to recommend. The Cronin and Taylor (1992) study did not appear to have a significant effect on repurchase intention, while Ranaweera and Neely (2003) study on some moderating effects on the service-customer retention link in England showed that perception of service quality has a direct linear relationship with customer purchase intention. The Lee and Feick (2001) and Gerpott et al (2001) study in south Korea and Germany respectively showed that call rate, quality of core service, clarity of voice positively impact on customer patronage. We posit that customer perception of service quality positively influences his intention to buy and behavioral usage.

$\mathrm{H}_{\mathrm{a} 1}$ : Service quality positively and significantly determines intention to use mobile phone.

\subsubsection{Customer Value and Customer Patronage}

Providing value to customers is still critical .Price has been observed as an important variable affecting the acceptance, usage, and even future patronage of GSM service. In supporting this, Woodruff (1997), Kollman (2000); Varki and Colgate (2001); and more recently Mohammed (2008) studies found that the lower the charges, the more customer consumed and the more customers will commit themselves to the telephone network. Chang and Width (1994) reported that price (customer-perceived value) has been found to be a major contributor to purchase and behavioral usage. In view of this, we hypothesized

$\mathrm{H}_{\mathrm{a} 2}$ : Customer value positively and significantly influences intention to use mobile phone services.

\subsubsection{Brand Image/Reputation and Customer Patronage}

The quality and quantity of brand promotion, image, and reputation can influence consumer patronage. Yi et al (2008) study found that corporate image positively relates intention to buy and behavioral patronage. Both brand image and Corporate Social Responsibility (CSR) have become crucial for influencing organizational value through customer intentional and behavioral patronages (Blumetha and Berystrom, 2003; Nguyen and Leblanc, 2001). Similarly, Andreassen and Lindestad, (1998) found that good corporate image and reputation help to increase firm's sales, market share and to establish and maintain a loyal relationship with customer. A favorable store image can influence repeated patronage (Dick and Basu, 1994). In a related study Chaudhuri and Holbrook (2001) and recently Boohene and Agyapong (2011) in Ghana showed that brand image and brand effect, combine, determine purchase loyalty and attitudinal loyalty. In view of this, we set forth this hypothesis:

$\mathrm{H}_{\mathrm{a} 3}$ : Brand image/reputation significantly influences intention to use of mobile phone service.

\section{Methodology}

A sample of 308 lecturers from state and federal universities in south - south region of Nigeria and users of GSM (MTN, Glo, Mtel, Etisalat and Zain) were selected through simple random sampling process. The main instrument for data collection was the questionnaire. Most questions in our questionnaire were taken from prior studies that had proven their validity and reliability, though revalidated to meet present and environmental realities. The questions were on a 5 -point Likert scale. The scores were coded 5 for strongly agree or strongly satisfied, 4 agree or satisfied, 3 for neutral or indifferent, 2 for disagree or dissatisfied and 1 for strongly disagree or highly dissatisfied.

\subsection{Measurement of Variables}

Service Quality: Service quality has a measure scale adopted from (Johnson and Sirikit, 2002) which used the 9 "SERVQUAL" measures. Customer Value: adopted (Martin - Consuegra et al (2008) measure of customer value. 
Brand Image \& Reputation adopted Chaudhuri and Holbrook (2006) measurement scale. Dependent Variable/Intention to Use: an emotional commitment/intention to use the brand in the future and the intention to recommend the brand to others was measured by (Fishbein and Ajzen 1975).

Bivariate analysis (Spearman's Rank Correlation test) has been used. A reliability test for each hypothesis, which entails the relationship of a construct and a dependent variable, has been conducted. The value of the Chronbach's alpha has been estimated to test whether the scales are reliable or not (Nunnaly, 1978), a coefficient of 0.7 or above was found and is desirable (Hair et al, 2001) in table 1.

Table 1. Reliability coefficients of variables measures

\begin{tabular}{lllll}
\hline s/no & Dimensions/measures of the study variables & Number of items & Number of case & Cronbach's Alpha \\
\hline 1 & Service quality & 9 & 308 & 0.919 \\
2 & Customer value & 4 & 308 & 0.888 \\
3 & Brand image/reputation & 4 & 308 & 0.758 \\
4 & Customer patronage( intention to use) & 4 & 308 & 0.876
\end{tabular}

Source: SPSS 15.0 version output

Step wise Regression analysis has also been done to show how much variability in dependent variable is caused by the variability in independent variables. For clarity, examining each hypothesis is encompassed into three steps: Reliability analysis, correlation analysis and regression analysis of the variables.

\section{Analysis}

Table 2. Frequencies and bar chart on age of the respondents

\begin{tabular}{lcccc}
\hline Valid & Frequency & Percent & Valid Percent & Cumulative Percent \\
\hline 25-29 years & 15 & 4.9 & 4.9 & 4.9 \\
30-34years & 48 & 15.6 & 15.6 & 20.5 \\
35-39 years & 78 & 25.3 & 25.3 & 45.8 \\
40-44 years & 106 & 34.4 & 34.4 & 80.2 \\
45 years and above & 61 & 19.8 & 19.8 & 100.0 \\
Total & 308 & 100.0 & 100.0 & \\
\hline
\end{tabular}

Source: Research Data, 2012

From table 2, out of the 308 respondents, $106(34.45 \%)$ were between age of 40-44 years, $78(25.3 \%)$ fall between age 35-39 years, 61 (19.8\%) were between 45 years and above, while 15 (4.9\%) are between age 25-29 years. It shows that majority of the respondents are in their forties years and above and are old enough to understand and respond to the questionnaire.

Table 3. Frequencies and bar chart on gender of the respondents

\begin{tabular}{lcccc}
\hline Valid & Frequency & Percent & Valid percent & Cumulative Percent \\
\hline Female & 61 & 19.0 & 19.0 & 19.8 \\
Male & 247 & 80.2 & 80.2 & 100.0 \\
Total & 308 & 100.0 & 100.0 & \\
\hline
\end{tabular}

Source: Research Data, 2012

From table 3 reveal that $247(80.2 \%)$ were male and $61(19.8 \%)$ were female. This shows that the majority of the respondents were male. 
Table 4. Significance value $(\alpha)$ and correlation coefficient $(\rho)$ of three hypotheses

\begin{tabular}{|c|c|c|}
\hline Predictor variable & Index & Intension To use \\
\hline \multirow[t]{3}{*}{ Service Quality } & $\mathrm{R}$ & $.634 * *$ \\
\hline & p-value & .0000 \\
\hline & Decision & Accept $\mathrm{H}_{\mathrm{A} 1}$ \\
\hline \multirow[t]{3}{*}{ Customer value } & $\mathrm{R}$ & $.877^{* *}$ \\
\hline & P-value & .000 \\
\hline & Decision & Accept $\mathrm{H}_{\mathrm{A} 2}$ \\
\hline \multirow[t]{3}{*}{ Brand image/reputation } & $\mathrm{R}$ & $.644^{* *}$ \\
\hline & P-value & .000 \\
\hline & Decision & Accept $\mathrm{H}_{\mathrm{A} 3}$ \\
\hline
\end{tabular}

** Significant $<0.05$.

From table 4 the result of hypothesis $\mathrm{H}_{\mathrm{a} 1}$ shows that service quality has $\mathrm{R} .634$ co-efficient and a p-value of 0.000 at a one tailed test. Since the p-value is less than alpha of 0.05 , this supports the hypothesis, then we accept $\mathrm{H}_{\mathrm{a} 1}$ that there is a strong, positive and significant relationship between service quality and intention to use mobile phone services. This means that the level and quality of GSM service quality offered as perceived by customer will influence customer intention to use.

The result on Hypothesis $\left(\mathrm{H}_{\mathrm{a} 2}\right)$ reveals that customer value has an R co-efficient of .877 and a p-value of 0.000 . Since the P-value is less than 0.05 Alpha at one-tailed test. This supports the stated hypothesis $\left(\mathrm{H}_{\mathrm{a} 2}\right)$, as such; customer value has a strong, positive and significant influence on intention to us

We observe that Brand image/reputation has co-efficient R.644 and P-value 0.000. This supports our hypothesis $\mathrm{Ha}_{3}$, since p-value is less 0.05 alpha at a one-tailed test. We accept the hypothesis that brand image/reputation has strong, positive and significant influence on intention to use mobile phone services. Generally, a positive explanation is that Nigerian consumers do have concern for service quality, brand image/reputation and customer value when they want to choose or decide to continue with a particular GSM service provider. The interrelationship among the variables is show in figure 1.

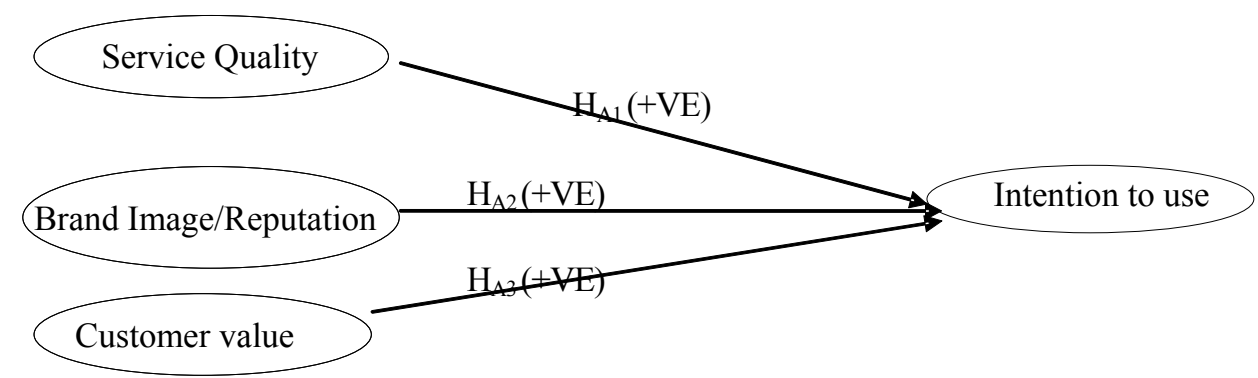

Figure 1. Conceptual framework of key factors influencing sustainable customer patronage of GSM and result of hypotheses finding

Source: Researchers’ review of literature, 2012

Table 5. Stepwise regression inclusion $r$ square modal summary

\begin{tabular}{lcccc}
\hline Model & R & R Square & Adjusted R Square & Std. Error of the Estimate \\
\hline 1 & $.440 \mathrm{a}$ & .194 & .191 & .97402 \\
2 & $.492 \mathrm{~b}$ & .242 & .237 & .94596 \\
3 & $.642 \mathrm{e}$ & .412 & .402 & .83742 \\
\hline
\end{tabular}

a. Predictors: (Constant), Brand Image and Reputation

b. Predictors: (Constant), Brand Image and Reputation, Customer Value

c. Predictors: (Constant), Brand Image and Reputation, Customer Value, Service Quality

d. Dependent Variable: Intention to use 
From table 5, step-wise regression analysis shows that only one independent variable, Brand image/reputation mostly explain (19.1\%) in the variation of the dependent variable, (intention to use) and was considered most important in the step wise regression. This also means that the variation of intention to use variable is explained only $4.8 \%(24.2-19.4)$ by customer value and is of second priority. Service quality explained $10.3 \%(41.2-24.2)$ in the dependent variable. So it can be drawn and concluded, from this study that brand image, service quality and customer value play positive and significant roles in explaining the variability of aspect of customer loyalty (intention to use). Furthermore, the regression model shows that $41.2 \%$ of the observed variability in intention to use $\left(R^{2}=.412\right)$ is explained by the independent variables- image, service quality and customer value.

\section{Conclusion and Implication}

These findings imply that good quality service is critical to inducing a patronage or keeping a consumer with a brand of telecommunication provider. There is a positive and significant relationship between service quality and customer intention to use. Thus, building intention to use (loyalty) depends to a large extent on ensuring that the firm provide and maintains simple, reliable and trouble-free service quality, and is proactive in "service innovation' especially with the identified nine SERVQUAL measures like- wide coverage, voice clarity, swift respond to service failure, communication of service failure and protection of transaction. Service quality delivery will drive/explain sustainable customer patronage. Thus, firms wanting to increase loyalty should focus on service quality.

The finding showed a positive and significant relationship between brand image/reputation and intention to use Mobile phone in Nigerian market. This means that customer consider the quality and quantity of brand image/reputation as represented in marketing promotion, brand partnering and investment in corporate social responsibility (CSR) when they want to patronize or make decision to continue to use any GSM service provider. Different promotion appeals, themes, and sales promotion especially the "image of the competitor' is considered very important in attitudinal patronages. So firms should consider brand image and reputation as driver of loyalty.

Customer value is positive and significant in influencing intention to use. Firm that offer real value that customer perceive as "fair, cheap and reasonable" may drive optimal customer intention to use. So mobile operators should think of the possibility of developing and strengthening customer perception of usefulness and segmenting service/value packages to meet price sensitive segments

The results of this study are to provide necessary reference to promote mobile marketing practice. Therefore, to have a strong competitive edge in the market, GSM service provider should proactively and primarily concern with delivering innovative service quality, brand image/reputation and customer value, and beyond in order to gain sustainable loyalty.

This study was limited by the fact that it was based on cross sectional data and the sample is not large enough for better generalization of the entire Nigerian market. It only considered attitudinal (intention to use) patronage. Consumer actual usage should be studied against these constructs too. More salient variables/constructs such as switching costs, customer service and socio- psychological variables should also be investigated.

\section{Acknowledgments}

We are sincerely grateful to Ogwo E. Ogwo for his initial proof reading the work and the invaluable comments of the anonymous reviewers and editors.

\section{References}

Aaker, D. A. (2004). A Brand Portfolio Strategy, Creating Relevance, Differentiation, Energy Leverage and Clarity. New York: Free Press.

Ahn, J. H., Hun, S. P., \& Lee, Y. S. (2006). Customer Churns Analysis: Churn determinants and mediation effects of Partial detection in the Korea mobile telecommunication service industry. Telecommunication Policy, 30, 552-569. http://dx.doi.org/10.1016/j.telpol.2006.09.006

Aminu, A., \& Hartini, A. (2008). Marketing Mix Drivers of Client GSM subscribers. Communication of the IBIMA, 1, 23-41.

Andreassen, T. W., \& Lindestad, B. (1998). Customer Loyalty and Complex Services. International Journal of Service Industry Management, 9(1), 7-23. http://dx.doi.org/10.1108/09564239810199923

Asheeta, B., Rowena, W., Subramanian, J., \& Peter, S. (2008). The Role of Mobile Phone in Sustainable Rural 
Poverty Reduction: ICT policy division. Global Information and Communication Department GICT, World development report.

Bigné, E., Ruiz, C., \& Sanz, S. (2007). Key Drivers of Mobile Commerce Adoption. An Exploratory Study of Spanish Mobile Users. Journal of theoretical and applied electronic commerce Research, 2(2), 193-209.

Blumenthal, D., \& Berystrom, A. (2003). Towards the Convergence of Parading and Corporate Social Responsibility. Brand Management, 10(4/5), 327-341. http://dx.doi.org/10.1057/palgrave.bm.2540128

Bolton, R. N., \& Drew, J. H. (1991). A Longitudinal Analysis of the Impact of Services Changes on Customer attitudes. Journal of Marketing, 55.

Bolton, R. N., \& Lemon K. N. (1999). A Dynamic Model of Customer Usage of Services: Usage as Antecedents and Consequences of Satisfaction. Journal of Marketing Research, 36(May), 171-186. http://dx.doi.org/10.2307/3152091

Boohene, R., \& Agyapong, G. K. Q. (2011). Analysis of the Antecedents of Customer Loyalty of Telecommunication Industry in Ghana: The Case of Vodafone (Ghana). International Business Research, 4(1), 229-240. Retrieved from http://www.ccsenet.org/journal/index.php/ibr/articledownload/8813/6459

Boulding, W., Kalra, A., Staclin, R., \& Zeithaml, V. A. (1993). A Dynamic Process model of service quality: From Expectations to Behavioral Intention. Journal of Marketing Research, 30, 7-27. http://dx.doi.org/10.2307/3172510

Chang, T. Z., \& Wildt, A. R. (1994). Price product information, and purchase intention: An empirical study. Journal of the academy of marketing sciences, 22, 16-27. http://dx.doi.org/10.1177/0092070394221002

Chaudhuri, A. M., \& Holbrook, M. B. (2001). The Chain of effect from Brand Trust and Brand Affect to Brand Performance: The role of brand loyalty. Journal of Marketing, 65(April), 81-93. http://dx.doi.org/10.1509/jmkg.65.2.81.18255

Churchill, G. A., \& Surprenant, C. (1982).An investigation into the Determinants of customer Satisfaction. Journal of Marketing Research, 19(4), 491-504. http://dx.doi.org/10.2307/3151722

Coyle, S., \& Gokey, T. (2005). Customer Retention is not enough. Journal of Consumer Marketing, 22(2), 101-105. http://dx.doi.org/10.1108/07363760510700041

Cronin, J. J., \& Taylor, S. A. (1992). Measuring Service Quality - a re-Examination and intention. Journal of Marketing, 56(3), 55-68. http://dx.doi.org/10.2307/1252296

Cronin, J. J., \& Taylor, S. A. (1994). SERVPERF vs SERVQUAL reconciling performance based and perception-minus-expectation measurement of service quality. Journal of Marketing, 58(January), 125-31. http://dx.doi.org/10.2307/1252256

Czepiel, J. A., \& Gilmore, K. (1987). Exploring the Concept of Loyalty in Services. Chicago: American Marketing Association.

David, M. C., Arturo, M., \& Agueda, E. (2007). An Integrated Model of Price, Satisfaction and Loyalty: An Empirical Analysis in the Service Sector. Journal of Product and Brand Management, 16(7), 459-468. http://dx.doi.org/10.1108/10610420710834913

Dick, A., \& Basu, K. (1994). Customer Loyalty: Toward and Integrated Conceptual Framework. Journal of Academy of Marketing Services, 22(2), 99-113. http://dx.doi.org/10.1177/0092070394222001

Drucker, P. F. (1973). Management: Tasks, Responsibilities, practices. New York, NY: Harper and Row.

Fishbein, Martin., \& Ajzen I. (1975). Belief, Attitude, Intention, Behaviour: An Introduction to Theory and Research, Reading. M.A. Addison Wesley Publishing Company.

Friedrich, R., Grone, F., Holbling, K., \& Peterson, M. (2009). The March of Mobile Marketing New Chances for Consumer Companies, New Opportunities for Mobile Operators. Journal of Advertising Research, 49(1), 54-61. http://dx.doi.org/10.2501/S0021849909090096

Gabriela, B., \& Badii, K. (2010). Impact of Mobile Services in Nigeria: How Mobile Technologies Are Transforming Economic and Social Activities. Pyramid Research, UK. Retrieved from http://www .pyramidresearch.com/download.htm? id=20

Gerpott, T. J., Rams, W., \& Schindler, A. (2001). Customer Retention Loyalty and Satisfaction in German Mobile Cellular Telecommunication Market. Telecommunication policy, 25(2001), 249-269. 
Hair, J. F. Jnr., Bush, R. P., \& Ortinau D. J. (2002). Marketing research: A practical approach for the new millennium. New York: Irwin McGraw-Hill.

Johnson, W. C., \& Sirikit. (2002). Service in the Thai Telecommunication industry: tool for achieving a sustainable competitive advantage. Managerial Decision, 40(7), 693-703. http://dx.doi.org/10.1108/00251740210438526

Jones, T. O., \& Sasser, W. E. (1995). Why Satisfied Customer Defect. Harvard Business Review, 73(6), 88-99.

Keaveney, S. M. (1995). customer switching behavior in service industries. Jourmal of marketing, 59(2), 71-82.

Keller, K. L. (2001). Building customer based brand-equity. Marketing Management, 10(2), 14-19.

Kollmann, T. (2000). The price/Acceptance Function: Perspective of Pricing Policy in European Telecommunication Markets. Journal of Innovation Management, 3(1), 7-14. http://dx.doi.org/10.1108/14601060010305210

Kotler, P. (1984). Marketing Management: Analysis Planning and Control (5th ed.). New Jersey: Prentice - Hall Inc.

Kotler, P., \& Keller K. (2006). Marketing Management (12th ed). U.S.A, New Jersey: Pearson Prentice Hall.

Kotler, P., Bouden, J. T., \& Jane, M. C. (2006). Marketing for Hospitality and Tourism (4th ed.). U.S.A. Pearson International.

Lee, J., \& Feick, L. (2001). The Impact of Switching cost on the customer satisfaction - loyalty link: Mobile phone service in France. Journal of Service Marketing, 15, 35-48. http://dx.doi.org/10.1108/08876040110381463

Lim, H., Widdows, R., \& Park, J. (2006). M-loyalty: Winning Strategies for Mobile Carriers. Journal of Consumer Marketing, 23(4), 208-218. http://dx.doi.org/10.1108/07363760610674338

McKenzie, J., \& Jurs, J. (1993). Planning, Implementing, and Evaluating Health Promotion Programs. New York: Macmillan Pub. Co.

Mohammed, I. S. (2008). The Analysis of Customer Loyalty in Bangladeshi Mobile Phone Operator Industry. Independent University, Bangladesh. Retrieved from http:/ /www.wbiconpro.com/501-Sohel pdf

Muminu, A., Anuluwapo, E., \& Aderemi, A. (2011). Consumer Preferences for GSM Network Product Services in Nigeria. University of Lagos, Nigeria.

Nguyen, N., \& Leblanc, G. (2001). Corporate image and corporate reputation in customers' retention decisions in services. Journal of Retailing and Consumer Services, 8(2), 27-36.

Nigeria Communications Commission. (2009). Market share report. Retrieved from www.Ncc.gov.ng/industry

Nordin, K. (2001). Christian science monitor.

Oliva, T. A., Oliver, R. L., \& MacMilan, I. C. (1992). A Catastrophe Model for Developing Service Satisfaction Strategies. Journal of Marketing, 56, 183-193. http://dx.doi.org/10.2307/1252298

Oliver, R. L. (1980). A Cognitive Model of Antecedents and Consequences of Satisfaction Decisions'. Journal of Marketing Research, 17, 460-490. http://dx.doi.org/10.2307/3150499

Oliver, R. L., \& Desarbo, W. S. (1988). Response Determinants in Satisfaction Judgements. Journal of Consumer Research, 14, 495-508. http://dx.doi.org/10.1086/209131

Oyeniyi, J. O., \& Abiodun, J. A. (2009). Switching Cost and Customers Loyalty in the mobile phone market: The Nigerian Experience. Business intelligence Journal, 3(1), 41-52.

Oyeniyi, O., \& Abiodun, A. J. (2008). Customer Service in the Retention of mobile users in Nigeria. African Journal of Business Management, 2(2), 26-31.

Pual, N., Howard T., \& Alexia La S. (2010). New Report Predicts Explosive European Growth for mobile broad brand. Retrieved from http://www.cellular-news.com/story/41409.php

Quan, S., Hao, C., \& Jianxin, Y. (2010). factors influencing the adoption of mobile service in China: An integration of TAM. Journal of computers, 5(5), 799-806.

Ranaweera, C., \& Neely, A. (2003). Some Moderating Effects on the Service Quality - Customer Retention. International Journal of Operation and Production Management, 2(23), 230-247. http://dx.doi.org/10.1108/01443570310458474 
Soderlund, M. (2011). Customer satisfaction and its consequences on different behavioral intention constructs. Journal of Consumer Behavior, 1, 145-166.

Teas, R. K., \& Agarwal, S. (2000). The effects of Extrinsic Product cues on consumers' perception of quality, sacrifice and value. Journal of the Academy of Marketing Science, 28, 278-291. http://dx.doi.org/10.1177/0092070300282008

Varki, S., \& Colgate, M. (2001). The role of Price Perception in an Integrated Model of Behavioural Intentions. Journal of Service Research, 3, 232-240. http://dx.doi.org/10.1177/109467050133004

Wan-Jin, L. (2009). The relationship between web-based service quality and customer loyalty. Nova Southeastern University.

Woodall, T. (2003). Conceptualizing value for the customer: An Attributional, structural and Dispositional Anaysis. Academy of Marketing Science Review, 12, 1526-1794.

Woodruff, R. B. (1997). Customer Value: The Next Source of Competitive Advantage. Journal of Academy of Marketing Science, 25(2), 139-153. http://dx.doi.org/10.1007/BF02894350

World Telecommunication/ICT Development Report. (2010). Monitoring the WSIS Target, A Mid-Term Review. Printed in Switzerland Geneva 2010 (International Telecommunication Union). Retrieved from http://www.uis.unesco.org/communication/documents/WTDR2010_e.pdf

Yi, H., Xiaoqin Y., \& Weiqing Z. (2009). How to Promote customer Loyalty of Chinese Mobile Operators: Case study of China Mobile. Master of Business Administration, University of BLEKINGE TEKNISKA HOGSKOLA BTH.

Zeithaml, V. A., \& Bitner M. J. (2000). Services Marketing, Integrating Customer Focus: A cross the firm (2nd ed.). U.S.A.: McGraw Hill, Irwin.

Zeithaml, V. A., Barry, L. L., \& Parasuramnan, A. (1996). The Behavioral Consequences of Service Quality. Journal of Marketing, 60(April), 31-46. http://dx.doi.org/10.2307/1251929

Zeithaml, V. A., Parasuraman, A., \& Barry, L. L. (1994). Re-assessment of Expectation as a Comparison Standard in Measuring Service Quality: Implication for further Research. Journal of Marketing, 58, 111-124. http://dx.doi.org/10.2307/1252255

Zeithmal, V. A. (1988). Customer Perceptions of Price, Quality and Value: A means End Model and Synthesis of Evidence. Journal of Marketing, 52(2), 22-41. 